J. Pijar MIPA, Vol. III, No.1, Maret $2008: 11$ - 16.

ISSN 1907-1744

\title{
MERCURY ANALYSIS AND CONCENTRATION IN SEAWATER OF SOUTHERN SUMBAWA
}

\author{
Surya Hadi ${ }^{1}$ \\ ${ }^{1}$ Study Program of Chemistry, Faculty of Mathematic and Sciences \\ University of Mataram, Jalan Majapahit62 Mataram, sur_hadi@telkom.net
}

\begin{abstract}
Current concerns over the negative impacts of $\mathrm{Hg}$ in the environment have led to the rapid progress of studies in this area. This progress has been directed to obtain analysis techniques that are able to accurately quantify Mercury $(\mathrm{Hg})$ at extremely low concentration in which it frequently occurs. As part of a study on the environmental aspects of deep-sea submarine tailing placement at the Batu Hijau Mine, Sumbawa, this paper discusses recent progress in $\mathrm{Hg}$ analytical techniques, followed by the application of several techniques to investigate $\mathrm{Hg}$ concentration in seawater in the vicinity of the tailing discharge location. Using cold vapour atomic fluorescence spectrometry, dissolved $\mathrm{Hg}$ was found to be at sub-ng/l (ppt) levels. No dissolved $\mathrm{Hg}$ signal associated with the tailing discharge was found with concentrations being similar to adjacent coastal waters.
\end{abstract}

Key words: tailing, STP system, Hg, analysis, and marine water

\section{INTRODUCTION}

The most concern of any of the heavy metal pollutants is mercury $(\mathrm{Hg})$ found as a trace component of many minerals. Related to human use of the element, Hg enters the environment from large number of miscellaneous sources such as discharge laboratory chemicals, batteries, broken thermometers, lawn fungicides, amalgam tooth filling, pharmaceutical products, metal mining and refining industries [1]. The toxicity of $\mathrm{Hg}$ has long been known and the more severe effects are neurological damage, including irritability, paralysis, blindness, or insanity; chromosome breakage; and birth defects [2].

The speciation of metallic elements including $\mathrm{Hg}$ affects their impact upon the environment. The usual form of $\mathrm{Hg}$ in aqueous solution is the $\mathrm{Hg}^{2+}$ ion. $\mathrm{Hg}$ has two oxidation states, $\mathrm{Hg}(\mathrm{I})$ and $\mathrm{Hg}(\mathrm{II})$, however the first of these, which contains the unusual ion ${ }^{+} \mathrm{Hg}-\mathrm{Hg}^{+}$is stable only as insoluble salt such as $\mathrm{Hg}_{2} \mathrm{Cl}_{2}$. The main complicating factor of $\mathrm{Hg}$ is its biological methylation to $\mathrm{CH}_{3} \mathrm{Hg}^{+}$and $\left(\mathrm{CH}_{3}\right)_{2} \mathrm{Hg}$, which converts inorganic $\mathrm{Hg}$ to forms, which are both more toxic and more lipophilic [3]. Therefore, the analytical methods for the assay of the elements in the environment must be directed to be able to differentiate between the various chemicals form of the element at very low levels.

The Batu Hijau copper-gold mine is located at Sumbawa island, in the province of West Nusa Tenggara, Indonesia. The open-pit mine is at an elevation of $450 \mathrm{~m}$ above sea level. Once removed from the open pit, the ore is crushed and conveyed $6.4 \mathrm{~km}$ to a grinding circuit and flotationbased concentrator. The final concentrate is then pumped via a $17.6 \mathrm{~km}$ pipeline to the port, where it is filtered and then shipped overseas. The tailings from the operation, consisting of finely ground rock (mostly sand) after the valuable minerals have been extracted, are disposed of by a deep-sea submarine tailings placement system (DSTP) [4]. This method of disposal was determined to have several advantages over on-land disposal and was approved by the Government of Indonesia [5].
An intensive study was conducted to observe the fiveyear performance of the DSTP system. Trace metal concentrations have been measured in samples of waters, sediments and fish tissues collected at locations in the vicinity of the PT NNT area [4]. This paper is focussed on review of $\mathrm{Hg}$ analytical method and $\mathrm{Hg}$ analysis in seawater by referring three main groups of studies $[6,4,7]$. Whilst $\mathrm{Hg}$ is not part of the Batu Hijau metallurgical process, it was included in this study for ensuring the level of the $\mathrm{Hg}$ in PT NNT environment.

\section{MATERIALS AND METHOD}

\subsection{Review of Hg Analytical Method}

To have knowledge of analytical method of $\mathrm{Hg}$, a mini review of the method was conducted on the basis of 32 references.

\subsection{Preparation of Hg Sample Bottles}

Fluorinated ethylene propylene (FEP) bottles (Nalgene, $1 \mathrm{~L})$ were used for sample collection and storage. Bottles were cleaned by filling with nitric acid ( $50 \%$, analytical grade) for 2 days and were rinsed with abundant quantities of Milli-Q water. The bottles were then filled with $10 \%$ ultrapure grade hydrochloric acid (Merck Tracepur) and left for a minimum of 3 days. The bottles were thoroughly rinsed with Milli-Q water, filled with Milli-Q water, capped and left for at least 2 days. The bottles were then emptied and 'double-bagged' in two polyethylene bags.

\subsection{Sampling Area}

An intensive sampling work was carried out over period 4-8 October 2004. The sampling localities were selected surrounding area of tailings discharge as shown on Figure 1. 


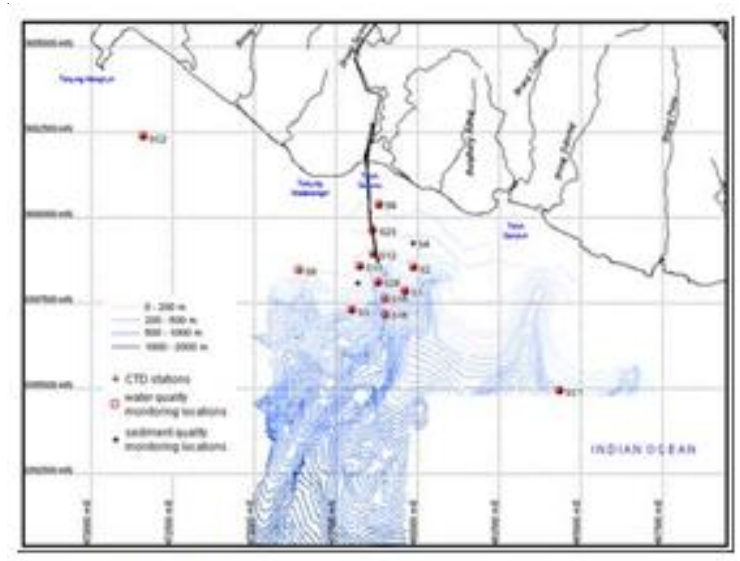

Figure 1. Locations of the Sampling Sites

\subsection{Water Samples}

Seawater samples were collected by three groups of researcher; CSIRO staff [4], West Nusa Tenggara Independent Team for PT NNT Environmental Monitoring [6], and PT NNT staff [7]. The sampling protocol followed rigorous 'clean hands/dirty hands' to avoid sample contamination $[8,9,10]$. This included the wearing of clean vinyl gloves for the handling of all sample bottles and sampling equipment. Water samples were collected from 7 marine sites using a Go-Flo bottle water sampler operated from the winch at the stern of the PT NNT environmental monitoring vessel PT Tenggara 9 powered by inboard motors.

The Go-Flo sampler had been previously cleaned by soaking in $10 \% \mathrm{HNO}_{3}$ and washed with copious amounts of deionised water. While not in use (e.g. between sites and during overnight storage), the Go-Flo was stored in a clean plastic bag housed within a plastic container. At the start of each day, the Go Flo was conditioned by deploying in open position at mid-water depth for 10 minutes at the first collection site. At subsequent collection sites, the Go-Flo was similarly conditioned for at least 2 minutes at each depth of water collection. Water samples for $\mathrm{Hg}$ were subsequently transferred to acid-washed FEP bottles. The samples were then split into three to be analysed in the three different laboratories used by the three groups of researchers $[4,6,7]$.

\subsection{Dissolved and Total Hg Analysis}

Dissolved $\mathrm{Hg}$ in the seawater was analysed in two laboratories; ALS Indonesia (Bogor, Indonesia), and SARPEDAL (Serpong, Indonesia) and total $\mathrm{Hg}$ analysis in both filtered and unfiltered seawater samples was conducted in CSIRO laboratory (Sydney, Australia). For dissolved Hg analysis, ALS Indonesia applied a procedure adapted from Standard Method for the Examination of Water and Wastewater (USEPA Method 7470A/7471A). The procedure involves a cold-oxidation of the acidified sample using bromine monochloride prior to reduction of the sample with stannous chloride. CVAAS was used to measure elemental
$\mathrm{Hg}$ formed. SARPEDAL followed the procedure of Indonesian National Standard (SNI 19-6964.2-2003) that used kalium permanganate as an oxidation agent and $\mathrm{Hg}$ analyser for $\mathrm{Hg}$ detection.

For total $\mathrm{Hg}$ analysis in both filtered and unfiltered seawater samples, CSIRO laboratory employed a procedure of gold-coated sand trap with cold vapour AFS $[11,12,13]$. Bromine monochloride $(\mathrm{BrCl})$ in hydrochloric acid $(\mathrm{HCl})$ was used to oxidase any organic $\mathrm{Hg}$ present to inorganic $\mathrm{Hg}$. Any residual $\mathrm{BrCl}$ was then destroyed by hydroxylamine solution. The mixture vessel was connected to a custombuilt purge trap system and stannous chloride solution was then added to reduce the inorganic $\mathrm{Hg}$ to elemental $\mathrm{Hg}$. The elemental $\mathrm{Hg}$ was purged from solution in a nitrogen stream and trapped on a gold-coated sand trap. The trap was transferred to a thermal desorption unit interfaced to a Brooks Rand atomic fluorescence spectrometer. The trap was connected to a $\mathrm{Hg}$-free helium gas stream and rapidly heated to $320^{\circ} \mathrm{C}$. The released $\mathrm{Hg}$ was quantified by the AFS.

\subsection{Quality Control}

To check analytical accuracy, aliquots of a CASS-4 for metals in saline waters National Research Council Canada (NRC) were analysed with each batch of samples. In addition, laboratory blanks, analytical duplicates and spiked samples were included. Method detection limits ( 3 times the standard deviation of the blank measurements) and recoveries were calculated from these data.

\section{RESULTS AND DISCUSSION}

\subsection{Overview of Hg Analytical Methods}

A need for determination of organic and inorganic $\mathrm{Hg}$ at very low concentrations in the environment leads to development of the analytical techniques. In the past, voltametric method was widely used for determination of $\mathrm{Hg}$ both in the field and laboratory. However, several limitations have been countered in the application of this technique. An anodic stripping voltametry (ASV) is able to determine dissolved $\mathrm{Hg}$ (II) in the form of $\mathrm{Hg}$ ions and unionised organic and inorganic $\mathrm{Hg}$ compounds in the concentration range 0.1 to $10,000 \mathrm{mg} / \mathrm{L}$ [14]. But, it cannot be used for direct determination of water-insoluble $\mathrm{Hg}$ compounds and cannot distinguish between organic and inorganic divalent Hg. Further development of this kind of technique is necessary since its operation doesnot require a sophisticated laboratory.

An extraction procedure is effectively used in determination of low concentrations of the different states of $\mathrm{Hg}$ (total, inorganic, and organic) followed by cold vapour atomic absorption spectroscopy (CVAAS) [15]. By tin(II) chloride under strongly acid conditions, inorganic $\mathrm{Hg}$ only was directly reduced to the metal $\mathrm{Hg}^{\circ}$ state and it was determined by CVAAS. Organic and inorganic $\mathrm{Hg}$ were extracted, with toluene, as the bromide derivatives and reextracted, together, into ammonium chloride solution. Organic $\mathrm{Hg}$ was converted into inorganic $\mathrm{Hg}$ by thermal digestion at $80-90^{\circ} \mathrm{C}$ in the presence of strong oxidants. 
These two states of $\mathrm{Hg}$ were determined together as total $\mathrm{Hg}$. Inorganic $\mathrm{Hg}$ was measured directly after preconcentration of the sample by toluene extraction. Toluene dissolved in aqueous phase after re-extraction of the sample was removed by heating for $30 \mathrm{~min}$ at $80-90$ degrees $\mathrm{C}$. Organic $\mathrm{Hg}$ was calculated as the difference between total and inorganic $\mathrm{Hg}$ with sensitivity reached $0.0001 \mathrm{ng} / \mathrm{mL}$ depending on sample volume.

In 1984, Margaret and Hirsh established the optimal conditions for use of sodium borohydride as the reducing agent before the direct determination of $\mathrm{Hg}$ in water, urine, and blood by atomic absorption spectroscopy. They evaluated the effects of $\mathrm{pH}$, temperature, and cupric sulphate concentration on the direct determination of both organic and inorganic compounds of $\mathrm{Hg}$. Accurate and precise quantification of $\mathrm{Hg}$ requires that the $\mathrm{pH}$ be between 9.3 and 9.5 , the reaction temperature above $25^{\circ} \mathrm{C}$, the reaction time longer than $1 \mathrm{~min}$, and, for urine samples only, the cupric sulphate concentration $10 \mathrm{mmmol} / \mathrm{L}$. The detection limit of the method is 1 to $2 \mathrm{ng}$ and the precision $(\mathrm{CV})$ is $3.8 \%$ for blood and $4.0 \%$ for urine.

Two-stage gold amalgamation with gas-phase detection is another choice for determination of total $\mathrm{Hg}$ in variety of matrices $[16,17,18,19]$. It is mainly consisted of two types of trapping system. For atmospheric $\mathrm{Hg}$, first gold trap called the field or sampling trap is used to collect and concentrate, and then it is transferred by thermal desorption to the second analytical or permanent trap equipped by $\mathrm{Hg}$ detector. For $\mathrm{Hg}$ in aqueous phase and solid-digestates, $\mathrm{SnCl}_{2}$ or $\mathrm{NaBH}_{4}$ reduction is employed to isolate and gasphase stripping is to collect the $\mathrm{Hg}$ onto the first trap. The introduction of $\mathrm{Hg}$ into spectrometer is by thermal desorption using an appropriate carrier-gas stream to the detection cell. Any one of several type of detector can be employed, namely atomic absorption [20,21], atomic fluorescence [20,22], microwave plasma emission [23,24] or photoacoustic $[25,26]$.

Liang and Bloom $[11,12,13,14,15]$ compared two techniques employing the two-stages gold amalgamation and a one-stage way in determination of elemental $\mathrm{Hg}$. When peak area was measured, and special attention paid to the gold trap orientation, the one-stage amalgamation procedure give the same precision, accuracy, and detection limits as the standard two-stages method [16]. By using an atomic fluorescence detector, an absolute detection limit was less than $1 \mathrm{pg}$ of $\mathrm{Hg}^{\circ}$ and the overall time for analysis was reduced from about 10 to 2 min per sample. Recoveries reached about $100 \%$ with RSDs of $<3 \%$ in determination of certified reference materials, intercalibration hair sample and lake water samples.

The analysis of methylmercury, the most toxic $\mathrm{Hg}$ species, has been done by Gas Chromatography (GC) with electron capture detection as a mercury chloride. The problem of this technique is that the detection method involving detection of chloride associated with $\mathrm{Hg}$ species requires exact cleanup procedure. Further development by involving aqueous phase drivatisation of $\mathrm{Hg}$ species with sodium tetraethylborate (STEB) was conducted by Rapsomanikis et al. in 1986 [27]. Dialkylmercury yielded by the reaction is more easily chromatographed than the chloride state and as a result, detection of element-specific $\mathrm{Hg}$ is significant improved on electron capture detector.

In 1984, Bloom developed a sophisticated method for $\mathrm{Hg}$ analysis by using aqueous phase ethylation and gas chromatography coupled with atomic fluorescence spectroscopy (GC-AFS). This method is able to accurately quantify methylmercury and inorganic $\mathrm{Hg}$ in sub parts-pertrillion that can be used for determination of $\mathrm{Hg}$ in ultratrace concentrations. But, the problem appeared in the ethylation step that tends to interferences from humic substance and chloride in particular. Because of that, separation of methylmercury from the sample matrix is necessary.

Nitrogen-assisted distillation and solvent extraction have been employed to separate methylmercury from natural water samples. The nitrogen-assisted distillation is very time consuming to require between $6-8 \mathrm{~mL} \mathrm{~h}^{-1}$ for the most effective distillation. The long distillation limits the maximum sample size [28]. Solvent extraction gave higher and more consistent recoveries. Yet, the method has a couple of limitations that are responsible for artifactual methylation of inorganic $\mathrm{Hg}$ added to sediments and water (varied from $0,001 \%$ of inorganic $\mathrm{Hg}$ present in clear, low organic waters to $0,1 \%$ in humic-rich waters). This effect is not likely to be significant in the most natural waters where methylmercury typically comprises $10 \%$ of total $\mathrm{Hg}$.

Steam distillation is another alternative technique to separate methylmercury from biological and sediment samples [29, 30, 31]. The rapid and efficient distillation of methylmerecury can be achieved since water vapour as carrier gas flows with rate $20 \mathrm{~mL} \mathrm{~min}^{-1}$ or greater. Bowles and Apte in 1998 developed and evaluated the use of this method in conjunction with aqueous-phase ethylation and GC-AFS to analyse methylmercury in natural waters [15]. The accuracy, precision, and detection limit of the method is comparable with nitrogen-assisted method. For wide range of natural fresh waters and estuarine waters, recovery

Table 1. Hg Intercomparison on Spiked Samples

\begin{tabular}{lcccc}
\hline Sample Code & $\begin{array}{c}\text { Concentration of } \\
\text { spike added, } \mu \mathrm{g} \text { L }\end{array}$ & $\begin{array}{c}\text { CSIRO } \\
\mu \mathrm{g} /\end{array}$ & $\begin{array}{c}\text { SARPEDAL } \\
\mu \mathrm{g} \text { L }\end{array}$ & $\begin{array}{c}\text { ALS } \\
\mu \mathrm{g} \text { L }\end{array}$ \\
\hline S.040 B & None & 0.0003 & $<0.5$ & $<0.05$ \\
S.040.M & 0.00492 & 0.0053 & $<0.5$ & $<0.05$ \\
S.040 S & 9.776 & 9.67 & 9.98 & - \\
\hline
\end{tabular}

$\mathrm{Hg}$ (II) spike added to sample in PT NNT Laboratory 
Table 2. Dissolved and Total Hg in Water Samples

\begin{tabular}{|c|c|c|c|c|}
\hline \multirow{2}{*}{$\begin{array}{l}\text { Sampling } \\
\text { Localities }\end{array}$} & \multicolumn{2}{|c|}{ CSIRO } & \multirow{2}{*}{$\begin{array}{c}\text { Sarpedal } \\
\text { Dissol. Hg, } \\
\mu g \text { L }\end{array}$} & \multirow{2}{*}{$\begin{array}{c}\text { ALS } \\
\text { Dissol. Hg: } \\
\mu g \text { L }\end{array}$} \\
\hline & $\begin{array}{c}\text { Total Hg, } \\
\mu \mathrm{g} L\end{array}$ & $\begin{array}{c}\text { Dissol. Hg: } \\
\mu \mathrm{g} \mathrm{L}\end{array}$ & & \\
\hline $\mathrm{S} 12 \mathrm{~s}$ & 0.0009 & 0.0010 & $<0.5$ & ND* \\
\hline $\mathrm{S} 12 \mathrm{~m}$ & 0.0004 & 0.0004 & $<0.5$ & ND \\
\hline $\mathrm{S} 12 \mathrm{~m}$ duplicate & 0.0003 & 0.0004 & $<0.5$ & ND \\
\hline $\mathrm{S} 12 \mathrm{~b}$ & 0.0004 & 0.0005 & $<0.5$ & ND \\
\hline $\mathrm{S} 15 \mathrm{~s}$ & 0.0003 & 0.0004 & $<0.5$ & ND \\
\hline S 15 s duplicate & 0.0003 & 0.0004 & $<0.5$ & ND \\
\hline $\mathrm{S} 15 \mathrm{~m}$ & 0.0005 & 0.0004 & $<0.5$ & ND \\
\hline S $15 b$ & 0.0008 & 0.0005 & $<0.5$ & ND \\
\hline$\$ 16 s$ & 0.0005 & 0.0004 & $<0.5$ & ND \\
\hline $\mathrm{S} 16 \mathrm{~m}$ & 0.0004 & 0.0004 & $<0.5$ & ND \\
\hline $\mathrm{S} 16 \mathrm{~b}$ & 0.0005 & 0.0004 & $<0.5$ & ND \\
\hline S23 s & 0.0004 & 0.0004 & $<0.5$ & ND \\
\hline $\mathrm{S} 23 \mathrm{~b}$ & 0.0003 & 0.0006 & $<0.5$ & ND \\
\hline$\$ 28 \mathrm{~s}$ & 0.0003 & 0.0005 & $<0.5$ & ND \\
\hline $\mathrm{S} 28 \mathrm{~m}$ & 0.0007 & 0.0005 & $<0.5$ & ND \\
\hline $\mathrm{S} 28 \mathrm{~b}$ & 0.0005 & 0.0005 & $<0.5$ & ND \\
\hline KEPMEN LH & - & 1 & & \\
\hline USEPA CCC & - & 0.94 & & \\
\hline
\end{tabular}

*ND (Not Detected) with detection limit $0.05 \mu \mathrm{g} \mathrm{L}$

of methylmercury chloride was $\sim 100 \%$. Poor recovery was found from seawater, but it is possible to be improved to $\sim 85 \%$ by addition of ammonium pyrrolidine dithiocarbamate (APDC). The absence of artifactual methylmercury and high sample throughput are advantages over other matrix separation methods.

Lambertson and Bjorn [32] carried out validation of a field-adapted procedure based on species-specific isotope dilution (SSID) methodology for trace-level determinations of methylmercury in mire, fresh and seawater samples. In the field study, mire water samples were filtered, standardised volumetrically with isotopically enriched $\mathrm{CH}_{3}$ ${ }_{200} \mathrm{Hg}^{+}$, and frozen on dry ice. The samples were derivative in the laboratory without further pre-treatment using sodium tetraethyl borate, $\mathrm{NaB}\left(\mathrm{C}_{2} \mathrm{H}_{5}\right)_{4}$, and the ethylated methylmercury was purge-trapped on Tenax columns. The analyte was thermo-desorbed onto a GC-ICP-MS system for analysis. Investigations preceding field application of the method showed that when using SSID, for all tested matrices, identical results were obtained between samples that were freeze-preserved or analysed unpreserved. For DOC-rich samples (mire water) additional experiments showed no difference in methylmercury concentration between samples that were derivatised without pretreatment or after liquid extraction. Extractions of samples for matrix-analyte separation prior to derivatisation are therefore not necessary. No formation of methylmercury was observed during sample storage and treatment when spiking samples with ${ }_{198} \mathrm{Hg}^{2+}$. Total uncertainty budgets for the field application of the method showed that for analyte concentrations higher than $1.5 \mathrm{pg} / \mathrm{g}$ (as $\mathrm{Hg}$ ) the relative expanded uncertainty (REU) was approximately $5 \%$ and dominated by the uncertainty in the isotope standard concentration. Below $0.5 \mathrm{pg} / \mathrm{g}\left(\mathrm{as} \mathrm{Hg}^{\circ}\right)$, the REU was $>10 \%$ and dominated by variations in the field blank. The uncertainty of the method is sufficiently low to accurately determine methylmercury concentrations at trace levels. The detection limit was determined to be $4 \mathrm{fg} / \mathrm{g}$ (as $\mathrm{Hg}$ ) based on replicate analyses of laboratory blanks. The described procedure is reliable, considerably faster and simplified compared to non-SSID methods and thereby very suitable for routine application of mercury speciation analysis.

\subsection{Concentrations of $\mathrm{Hg}$ in Seawater}

The data for quality control are summarised in Table 1 indicated that adequate analytical performance was achieved.

The use of two different techniques [6,7] in analysis of $\mathrm{Hg}$ in marine water collected from vicinity of tailings discharge and other stations on south coast of Sumbawa found that no dissolved $\mathrm{Hg}$ detected. Further investigation was done to have quantitative concentrations by using very sensitive method. A gold-coated sand trap with AFS was employed to achieve sub-ppt level of dissolved and total $\mathrm{Hg}$ in the marine water samples [4]. Table 2 shows $\mathrm{Hg}$ concentrations obtained by the three groups of researchers.

The concentrations of both dissolved and total $\mathrm{Hg}$ at the South Coast of Sumbawa and Senunu Canyon sites were detected in extremely low, ranging $0.0003-0.0010 \mu \mathrm{g} / \mathrm{L}$ (sub-part-per-trillion, $\mathrm{ng} / \mathrm{L}$ range). The highest concentration measured was $0.0010 \mu \mathrm{g} / \mathrm{L}(1 \mathrm{ng} / \mathrm{L})$ in a surface 
Table 3. Comparison of trace $\mathrm{Hg}$ from some locations

\begin{tabular}{lc}
\hline Locations & $\begin{array}{l}\text { Total Hg } \\
\mu \mathrm{L} \text { L }\end{array}$ \\
\hline $\begin{array}{l}\text { This Study } \\
\text { (Mean for S. coast control sites) }\end{array}$ & $-0.0005=0.0002$ \\
Pacific Ocean & $0.0003-0.0004$ \\
(Surface waters) & \\
NSW Coastal Waters (off-shore) & $\quad 0.0014$ \\
(Apte et al. 1998) & \\
\hline Data summarised in Apte et al. (1998) \\
2Mean of all sites
\end{tabular}

of the seawater sample collected from site S12. This value is around 1000 times below levels of Indonesian or USEPA regulatory concern. The Hg concentrations were similar for all sites and depths confirming that there was no seawater signature of dissolved $\mathrm{Hg}$ associated with the tailings discharge. The concentrations are similar to adjacent coastal waters as shown on Table 3 .

\section{IV.CONCLUSIONS}

The current development of $\mathrm{Hg}$ analytical methods has fulfilled the need of extremely low concentration detection. A selective, accurate and practical method on the basis of a voltametry is potensial to be developed to fulfil the demand of laboratory where no sophisticated analytical instrumentation available. To differenciate $\mathrm{Hg}$ forms (total, inorganic, and organic), an extraction procedure followed by CVAAS can be effectively used in determination of mercury in low concentrations. The sensitivity of meassurement can be improved by using AFS. Aqueous phase ethylation and gas chromatography coupled with atomic fluorescence spectroscopy (GC-AFS) is able to accurately quantify methyl $\mathrm{Hg}$ and inorganic $\mathrm{Hg}$ in subppt level. A field-adapted procedure based on SSID tehnique for trace-level determinations of methylmercury was reliable, considerably faster and simplified and can be developed for routine applications of metylmercury speciation analysis in a wide range of water samples.

Three different of $\mathrm{Hg}$ analytical methods were used to investigate $\mathrm{Hg}$ concentrations in seawater in the vicinity of the tailings discharge location of PT NNT. The first two (SARPEDAL and ALS Indonesia) indicated that $\mathrm{Hg}$ concentrations in the sampling sites below the laboratories detection limits. By using Single stage Gold Amalgamation with CVAFS, CSIRO Laboratory found that total $\mathrm{Hg}$ in both unfiltered and filtered seawater samples to be at sub-ng/l (ppt) levels (0.0003-0.0010 ug/L), being similar to adjacent coastal waters. These outcomes have confirmed that tailings released by PT NNT is not a potential source of $\mathrm{Hg}$.

\section{ACKNOWLEDGMENT}

We would like to thanks S.C. Apte, S.L. Simpson, R.F. Jung, G.E. Batley, L.T. Hales and B. Warden for their permission in using CSIRO data, G. Batterham for the paper correction and PT NNT General Manager and West Nusa Tenggara Government for funds support in conduction of the study.

\section{REFERENCES}

[1] Manahan, S.E., 1990. Lewis Publishers, Chelsea, Michigan.

[2] Manahan, S.E., 1993. Lewis Publishers, Chelsea, Michigan.

[3] Bunce, N.J., 1991. Wuerz Publishing Ltd Winnipeg, Canada.

[4] Apte, S.C.; Simpson, S.L.; Jung, R.F.; Batley, G.E.; Hales, L.T. and Warden, B., 2005. PT Newmont Nusa Tenggara, Environmental Due Diligence Study, CSIRO, Sydney.

[5] ANDAL, 1996. Environmental Impact Assessment, Batu Hijau Copper-Grold Project, Jereweh District, Sumbawa Regency, Nusa Tenggara Province, Indonesia, October 1996.

[6] Hadi, Surya; Karnan; Mahrup; Bachtiar, Imam; AlIdrus, Agil; Sayuti, R.H; Asikin, Zaenal; Djobeng, Muctar; Adnan, N.M., 2004. NTB Independent Teamfor PT NnT Environmental Monitoring, Bapedalda Nusa Tenggara Barat.

[7] PT NNT, 2005. Summary Report of Marine Ecology Monitoring 1997-2004.

[8] USEPA, 1996. US Environmental Protection Agency, Office of Water Engineering and Analysis Division (4303), Washington DC 20460.

[9] Apte, S.C.; Batley, G.E.; Szymczak, R.; Rendell, P.S.; Lee, R.; Waite, T.D. 1998. Marine and Freshwater Research 49, 203-214.

[10] Apte, S.C.; Batley, G. E.; Maher, W.A. 2002. Handbook of Environmental Monitoring. Burden, F., Forstner, U., Guenther, A., and McKelvie, I., Eds, McGraw Hill, New York.

[11] Liang, L. and Bloom, N.S., 1993. Anal. Atom. Spectrom. 8, 591.

[12] Liang, L. and Bloom, N.S. 1993. J. Anal. Atom. Spectro. 8, 591.

[13] Liang, L., and Bloom, N.S., 1993. J. Anal. Atom. Spectro. 8, 591.

[14] Pyle, S and Miller, E.L., ?. EMSL-LV/ORD/USEPA.

[15] Bowles, K.C. and Apte, S.C., 1998. Anal. Chem. 70, 395.

[16] Fitzgerald, W.F. and Gill, G.A., 1979. Anal. Chem. 51,1714 .

[17] Bloom, N.S. and Crecelius, E.A., 1983. Mar. Chem. 14, 49.

[18] Gill, G.A. and Fitzgerald, W.F., 1987. Mar. Chem. 20, 227.

[19] Horvat, M. and Lupsina, V., 1991. Anal. Chim. Acta. 243, 71 .

[20] Nakahara, T.; Tanaka, T.; Musha, S., 1978. Bull. Chem. Soc. Jpn. 51, 2020.

[21] Yamamoto, J.; Kaneda, Y.; Hikasa, K., 1983. Int. J. Environ. Anal. Chem. 16,1.

[22] Bloom, N.S.; Fitzgerald, W.F., 1988. Anal. Chim. Acta. 208, 151.

[23] Nojiri, Y.; AkiraO.; Fuwa, K., 1986. Anal. Chem. 58, 544.

[24] Ballantine, D.S.; Zoller, W.H., 1984. Anal. Chem. 56, 1288. 
J. Pijar MIPA, Vol. III No.1, Maret 2008 : 11 - 16.

[25] Patterson, J.E., 1982. Anal. Chim. Acta. 136, 321.

[26] Patterson, J.E., 1984. Anal. Chim. Acta. 164, 119.

[27] Rapsomanikins, S; Donard, O.F.X..; Weber, J.H., 1986. Anal. Chem. 58, 35.

[28] Horvat, M.; Bloom, N.S.; Liang, L., 1993a. Anal. Chim. Acta 281,135.

[29] Uchida, M.; Horakawa, K.; Inoue, T., 1961. Kumamoto Med. J. 14,181.

[30] Floyed, M. and Sommers, L.E., 1975. Anal. Lett. 8, 525.

[31] Collett, D.L.; flemming, D.E.; Taylor, G.A., 1980. Analyst 105, 897.

[32] Lambertsson L, Bjorn E., 2004. Anal Bioanal Chem. 380(7-8), 871 . 